\title{
Erratum to: Effect of Lung Fibrosis on Glycogen Content in Different Extrapulmonary Tissues
}

\author{
Elizabeth Lage Borges • Marina de Barros Pinheiro $\cdot$ Luana Oliveira Prata • \\ Wesley Araújo Sales · Yuri Augusto Junqueira Belém Silva • \\ Marcelo Vidigal Caliari • Maria Glória Rodrigues-Machado
}

Published online: 28 February 2014

(C) Springer Science+Business Media New York 2014

Erratum to: Lung (2014) 192:125-131

DOI 10.1007/s00408-013-9539-4

Unfortunately, the given name and family name of the last author was incorrectly published in the original publication. The author name is corrected in this erratum.

Therefore, the first name is Maria Glória and the last name is Rodrigues-Machado (M. G. Rodrigues-Machado).

The online version of the original article can be found under doi:10.1007/s00408-013-9539-4.

E. L. Borges $(\varangle) \cdot$ M. de Barros Pinheiro ·

W. A. Sales - Y. A. J. B. Silva

Departamento de Fisiologia e Biofísica, Instituto de Ciências

Biológicas, Universidade Federal de Minas Gerais, Av. Antônio

Carlos, 6627, Belo Horizonte, MG 31270-010, Brazil

e-mail: borgesel@icb.ufmg.br

L. O. Prata · M. V. Caliari

Departamento de Patologia Geral, Instituto de Ciências

Biológicas, Universidade Federal de Minas Gerais,

Belo Horizonte, MG, Brazil

M. G. Rodrigues-Machado

Faculdade de Ciências Médicas de Minas Gerais,

Belo Horizonte, MG, Brazil 